\title{
A rinha de galos, o direito dos animais e o meio ambiente na ótica do STF - uma análise da ADI 1856/RJ
}

\author{
ROOSTER FIGHTING, ANIMAL RIGHTS AND THE \\ ENVIRONMENT FOR THE BRAZILIAN FEDERAL \\ SUPREME COURT - A REVIEW OF THE ADI 1856/RJ \\ * Carolina Carneiro Lima \\ ** Beatriz Souza Costa
}

Resumo: O presente texto realizou uma análise das questões articuladas e da decisão proferida pelo STF na ADI 1856/RJ que discute a validade jurídica da Lei promulgada pelo Estado do Rio de Janeiro que regulamenta a prática da Rinha de Galos. A norma foi declarada inconstitucional em razão da crueldade a qual são submetidas as aves da raça combatente. A decisão teve como parâmetro o princípio da dignidade humana e a determinação constitucional de que o meio ambiente deve ser protegido pelo Poder Público e pela coletividade. O estudo é realizado sob a concepção antropocêntrica. O objetivo é analisar a questão da crueldade contra os animais e a proteção do homem contra a perda da sua própria dignidade com ações violentas. Para a pesquisa foi usado o método dedutivo, por meio de pesquisa bibliográfica para responder ao problema que tem seu cerne no motivo de se proteger os animais de atos cruéis.

* Graduada em Direito pela PUCMinas, especialista em Direito Público com ênfase em Direito Constitucional pela Universidade Cândido Mendes e mestranda em Direito Ambiental e Desenvolvimento Sustentável pela Escola Superior Dom Helder Câmara. Email: carol carneirolima@yahoo.com.br

** Mestre e Doutora em Direito Constitucional pela UFMG. Pró-reitora de Pesquisa da Escola Superior Dom Helder Câmara. Professora de Graduação e Pósgraduação no Curso de Mestrado em Direito Ambiental e Desenvolvimento Sustentável da ESDHC. Email: E-mail: carolcarneiro lima@yahoo.com.br

Palavras-chave: inconstitucionalidade, rinha de galos, proteção dos animais, crueldade, dignidade humana.

Abstract: The present paper realized an analysis of the articulated issues and the decision rendered by the Supreme Court in ADI 1856/RJ that discusses the legal validity of the Law enacted by the state of Rio de Janeiro that regulates the practice of the rooster fighting. The standard was declared unconstitutional by the reason of the cruelty, which is subjected the combatant race birds. The decision had as a parameter the principle of human dignity and the constitutional determination that the environment must be protected by the government and by the community. The study is realized under the anthropocentric conception. The goal is to analyze the issue of cruelty against the animals and the protection of the man against the loss of their own dignity with violent actions. For the study, the deductive method was used, by the means bibliographic search to answer the problem that has its heart in reason to protect animals from cruel acts.

Keywords: unconstitutionality, rooster fighting, animal welfare, cruelty, human dignity.

Revista do Direito Público, Londrina, v.10, n.3, p.91-118, set./dez.2015 | DOI: 10.5433/1980-511X.2015v10n3p91 


\section{INTRODUÇÃO}

A Ação Direta de Inconstitucionalidade $n^{0} 1856$, interposta pelo Procurador-Geral da República pretende a manifestação do Supremo Tribunal Federal acerca da validade jurídico constitucional da Lei Fluminense $n^{\circ}$ 2895/98 de 20 de março de 1998. A norma estadual autoriza a criação e a realização de exposições e competições entre aves das raças combatentes (fauna não silvestre) para preservar e defender o patrimônio genético da espécie gallusgallus.

A briga ou rinha de galos desperta interesse e contestação na sociedade. Apresenta conflito entre uma pretensa (possível) manifestação cultural e a proteção do meio ambiente cujos preceitos encontram-se esquadrinhados no art. 225, caput da CR. Em razão da apontada antinomia entre a norma regional e a Carta Magna é que surgiu a necessidade de manifestação da Corte Suprema do país em relação à prática do galismo.

Assim, para o estudo da ADI $n^{\circ} 1856 /$ RJ iremos apresentar inicialmente as especificidades da norma vergastada pelo Ministério Público da União, os argumentos de propositura e aqueles apresentados pelos interessados Assembleia Legislativa do Estado do Rio de Janeiro e o Governador do Estado de onde emanou o texto legislativo em estudo. Em seguida, discorreremos sobre a rinha de galos, o direito dos animais, o meio ambiente e o direito ambiental na concepção apresentada pelo STF no julgamento da ADI. O antropocentrismo e biocentrismo serão abordados e verificada a posição da Corte Suprema e da Constituição da República em relação ao tema.

O marco teórico será o próprio acórdão do Supremo Tribunal Federal e o seu parâmetro de entendimento acerca da proteção da fauna e do meio ambiente. Atingiremos a noção de meio ambiente como direito humano de terceira dimensão e sua análise e entendimento basear-se-ão no homem, em sua dignidade.

Não nos ateremos, neste estudo, aos aspectos processuais, tampouco, às questões de competência e técnica legislativa. Não analisaremos teoricamente a Ação Direta de Inconstitucionalidade, suas espécies e finalidade. Faremos uma descrição sucinta da ação proposta, mostrando as argumentações e os debates desenvolvidos para se chegar ao cerne meritório da demanda posta em juízo. O mérito da ação, sim, é o nosso objetivo. As matérias ventiladas serão descritas e pontuadas, assim como as motivações expostas pelo Ministro relator e pelos demais Ministros. 
O foco precípuo, como mencionado, é o direito material envolvido, ou seja, o direito dos animais e a proteção do meio ambiente, compreendido de maneira holística - necessário à sadia qualidade de vida da presente e das futuras gerações.

Veremos que a tutela do ambiente, em sua integralidade, confere poder ao homem, não a cada indivíduo de forma particularizada, mas a cada um na composição de uma coletividade social. Este referencial reflete um processo de ampliação da proteção, afirmando, em contrapartida, os direitos humanos.

Nosso olhar é analítico e o método utilizado é o dedutivo, voltado aos argumentos sustentados pelos julgadores da Corte Constitucional, desenvolvendoos por meio de estudos doutrinários para o entendimento do tema e para reforçar as bases jurídicas.

Ao final, alcançaremos a visão de que as regras insculpidas na Lei estadual do Rio de Janeiro $n^{\circ} 2895 / 98$ são inconstitucionais por ofensa aos dispositivos contidos no art. 225 , caput e art. $225, \S 1^{\circ}$, inciso VII da CR, assim como afrontam os planos contidos em declarações internacionais. Estas últimas mostram-nos que a preocupação e atenção com o meio ambiente é compromisso das Nações com toda a humanidade que depende de um direito ambiental eficaz para uma vida digna. Faz-se, assim, uma reverência aos princípios da solidariedade e da cooperação.

Não há dúvidas sobre a importância do meio ambiente adequadamente preservado para a sadia qualidade de vida da geração atual e da sua manutenção neste estado para garantir dignidade às futuras gerações. Este é o legado que deixaremos. Esta é a natureza de direitos intergeracionais. Não há desconexão entre a proteção da fauna e a proteção da vida do gênero humano. Todos se interligam e têm o mesmo direito complexo a um meio ambiente ecologicamente equilibrado.

Fica clara, portanto, a conexão presente entre a existência ambiental digna do ser humano e o seu dever ético-jurídico de preservar e respeitar os elementos integrantes do meio ambiente, precisamente, no caso em voga, a proteção da fauna de atos de crueldade.

\section{COMPREENDENDO A AÇÃO DIRETA DE INCONSTITU- CIONALIDADE 1856/RJ, O CASO EM ESTUDO}

A Ação Direta de Inconstitucionalidade $n^{\circ} 1856 / \mathrm{RJ}$ foi proposta pelo Procurador-Geral da Repúbica e teve como interessados o Governador do Estado 
do Rio de Janeiro e a Assembleia Legislativa daquela unidade da federação. A ação foi julgada em Sessão Plenária, sob a presidência do Ministro Cezar Peluso, sendo seu relator, o Ministro Celso de Mello. As preliminares arguidas foram rejeitadas e o mérito julgado procedente para declarar a inconstitucionalidade da Lei estadual fluminense $n^{\circ} 2.895$ de 20 de março de 1998. Tanto a rejeição das preliminares quanto o mérito foram decididos por unanimidade de votos, salientando-se, por necessário, a ausência justificada da Ministra Ellen Gracie e a existência do voto do Ministro Presidente neste caso.

Participaram da sessão além do Ministro presidente e do Ministro relator, os senhores Ministros Marco Aurélio, Gilmar Mendes, Ayres Britto, Joaquim Barbosa, Ricardo Lewandowski, Cármen Lúcia, Dias Toffoli e Luiz Fux.

Compreendidos os parâmetros gerais da ação constitucional a qual dedicamos nosso olhar, partiremos para o entendimento dos argumentos que levaram à discussão e à decisão proferida em 26 de maio de 2011.

A interposição da ADI 1856/RJ, visa, em controle normativo abstrato, o questionamento da validade jurídico constitucional da lei fluminense (Lei $n^{\circ}$ 2.895/ 98) que autoriza a criação e a realização de exposições e competições entre aves das raças combatentes (fauna não silvestre), sustentando ser para a preservação e defesa do patrimônio genético da espécie gallus-gallus. Tal lei regulamenta a prática da rinha de galos como esporte. As razões iniciais apontam a inconstitucionalidade da regra por ofensa ao preceito insculpido no art. 225, caput e art. 225, $\S 1^{\circ}$, inciso VII da Constituição da República. Sustenta, o Procurador-Geral da República, que a prática da competição submete os animais a crueldade e que há flagrante antinomia entre a lei estadual e a Constituição o Estado autoriza prática que, compulsoriamente, deveria coibir. Argumenta, ainda, que a proibição de submissão de animais a práticas cruéis estende-se a todos os exemplares da fauna, mesmo os domesticados e os em cativeiro (BRASIL, Supremo Tribunal Federal, ADI 1856, Relator Min. Celso de Mello, 2011).

A Assembleia Legislativa do Estado do Rio de Janeiro, como interessada, prestando informações, manifestou pela improcedência da ação direta, pretendendo o reconhecimento da validade constitucional plena da lei contestada. Aduz que com a normatização da prática têm-se maior controle sob a atividade e que a rinha de galos, do ponto de vista social, promove a integração de comunidades do interior do Estado, inclusive, gerando empregos. Alega inexistir afronta ao texto constitucional e ser concorrente a competência para legislar sobre meio ambiente entre os entes federados. Comenta que a 
A rinha de galos, o direito dos animais e o meio ambiente na ótica do STF - uma anÁlise da ADI 1856/RJ

Magna Carta menciona a palavra fauna, da qual estão excluídos os animais domésticos e domesticados como os galos de briga - aves domésticas -, afastando-se, portanto, o âmbito material de incidência da norma constitucional. Motiva, por fim, que a lei maior proíbe a ação do homem contra o animal e na prática do galismo não há interferência direta do homem, as aves lutam por seu espírito atávico, não havendo imposição que as forcem a combater (BRASIL, Supremo Tribunal Federal, ADI 1856, Relator Min. Celso de Mello, 2011).

Já o excelentíssimo Governador do Estado do Rio de Janeiro, também interessado na ADI em questão, requer a improcedência da ação sob os argumentos de que a inicial é inepta e que na lei não há forma de se ver alguma crueldade ou desproteção aos animais. Ventila que a norma constitucional é de eficácia limitada, precisando de definição acerca do que seriam práticas cruéis. E uma vez fixados esses conceitos, seria o caso de ilegalidade e não de inconstitucionalidade (BRASIL, Supremo Tribunal Federal, ADI 1856, Relator Min. Celso de Mello, 2011).

A medida cautelar restou deferida e a norma questionada teve a sua eficácia suspensa liminarmente.

O Advogado-Geral da União, por sua vez, opinou pela improcedência do pedido acolhendo os argumentos esposados pelos interessados.

Essa é a construção dialética formulada pelas partes envolvidas na ação constitucional. Agora, cabe-nos mostrar as razões de decidir proferidas pelo Pleno do Supremo Tribunal Federal.

Inicialmente, foi analisada a questão preliminar de inépcia da inicial que não restou acolhida pelos julgadores, por ser a peça inaugural juridicamente idônea e formalmente apta a viabilizar a fiscalização abstrata de constitucionalidade. Em seguida, adentrou-se ao cerne meritório.

A ADI questiona de forma global, em sua finalidade última, e não artigo por artigo, a lei estadual fluminense $n^{\circ} 2895 / 98$. A questão precípua sob a relatoria do Ministro Celso de Mello é a "prática de atos revestidos de inquestionável crueldade contra aves das raças combatentes (gallus-gallus) que são submetidos a maus-tratos, em competições promovidas por infratores do ordenamento constitucional e da legislação ambiental" (BRASIL, Supremo Tribunal Federal, ADI 1856, Relator Min. Celso de Mello, 2011, p. 293). Para o julgador, trata-se de "comportamento delinquencial" que transgride o preceito contido no art. $225, \S 1^{\circ}$, inciso VII da CR. 
Em sua fundamentação, o Ministro relator tratou o meio ambiente de forma ampla e abrangente e a sua preservação como integral. Assim, qualquer prática que submeta animais à crueldade deve ser vedada, dando-se efetividade às normas constitucionais. Alerta que há conexão íntima entre o dever éticojurídico de preservar a fauna e a "própria subsistência do gênero humano em um meio ambiente ecologicamente equilibrado" (BRASIL, Supremo Tribunal Federal, ADI 1856, Relator Min. Celso de Mello, 2011, p. 295). Sustenta que o meio ambiente é direito humano de terceira geração (novíssima dimensão) e que se projeta em declarações internacionais como compromisso das Nações perante a humanidade.

Elucida, também, que a proteção conferida aos animais pela Constituição abrange os animais silvestres e os animais domésticos ou domesticados, sejam eles nativos ou exóticos, atingindo os galos de briga. O texto constitucional utiliza-se de cláusula genérica, vedando qualquer forma de submissão de animais a práticas cruéis. Enfatiza que as atividades e experiências cruéis com animais são incompatíveis com a norma constitucional, sustentando que tais práticas não podem ser camufladas sob a denominação de atividade desportiva, prática cultural ou expressão folclórica. Aceitar tal argumento seria referendar uma tentativa de fraudar o cumprimento da norma constitucional de proteção da fauna com objetivos mais emblemáticos que é a proteção contra a crueldade.

Iniciados os debates, os demais Ministros manifestaram-se sobre a inadmissibilidade da prática do galismo e apontaram não somente pela incompatibilidade em relação aos princípios-regra constitucionais, mas, também, por ser, a atividade, crime ambiental preceituado no art. 32 da Lei ${ }^{\circ}$ 9.605/98.

Discorrem que o Estado brasileiro tem a incumbência, em quaisquer de suas dimensões, de impedir a prática de crueldade contra animais, sendo que ela ofende o próprio cerne da dignidade humana, pois estimula o ser humano a suas pulsões mais primitivas e irracionais (BRASIL, Supremo Tribunal Federal, ADI 1856, Relator Min. Celso de Mello, 2011). A dignidade humana, por sua vez é princípio caro ao nosso ordenamento jurídico, apresentase como fundamento da República Federativa do Brasil. Concluem as discussões, com o voto da Ministra Cármen Lúcia.

Eu acho que o $\S 1^{\circ}$, ao se referir à vedação que o Poder Público deve impor, é exatamente no sentido de que, se a coletividade sozinha não conseguir 
A rinha de galos, o direito dos animais e o meio ambiente na ótica do STF - uma análise da ADI 1856/RJ

fazer com que o folclore e a cultura seja produção em benefício da vida e da dignidade, incumbe ao Estado vedar práticas que conduzam a isso. É uma tônica que, a meu ver, precisamos dar; não é o Estado que tem de ficar proibindo ou impondo às pessoas condutas que dignifiquem, mas a sociedade é que deve fazer isso. A sociedade tem de ser democrática para termos um Estado verdadeiramente democrático, na linha do que Vossa Excelência acaba de se referir. Quer dizer, há tanta violência, mas a violência, que parte de cada um, precisa ser coibida só nos excessos.

Acho que a interpretação do Ministro Celso de Mello, que eu acompanho às inteiras, é exatamente de um constitucionalismo social, neste sentido: a incumbência é da Sociedade. O Poder Público tem de atuar não o tempo todo, entrando na casa da gente ou na vida da gente, mas cada um de nós, na nossa casa, sendo digno (BRASIL, Supremo Tribunal Federal, ADI 1856, Relator Min. Celso de Mello, 2011, p. 338/339).

Não há dúvidas sobre o posicionamento do STF em relação ao meio ambiente e a proteção da fauna - é dever de todos e exercício de cidadania. Por meio da consciência ambiental, constrói-se ou dão-se passos largos para a construção de uma sociedade democrática e de um Estado Democrático de Direito. A sociedade tem sua responsabilidade juntamente com o Estado de edificar a verdadeira democracia. A dignidade humana, maculada pela ausência de respeito ao meio ambiente, somente se consolidará a partir da cidadania e da visão plural e completa do ambiente. A cidadania e o pluralismo são valores que se harmonizam com a ideia de democracia (LEITE, 2013), elemento constitutivo de um Estado Democrático de Direito.

\section{A RINHA DE GALOS E A PROTEÇÃO DOS ANIMAIS}

A análise da rinha de galos e a proteção jurídica dos animais passam pelo mesmo paradigma ético-jurídico concebido pela Constituição da República e estendido, pelo ordenamento jurídico, para a concepção e compreensão de todos os elementos componentes do meio ambiente. A leitura ecológica que se tem do ambiente atualmente requer a interação de fatores físicos, químicos, biológicos, sociais e econômicos. Trata-se de uma interação multidisciplinar (PADILHA, 2010). A proteção tem como parâmetro basilar o homem, em sua humanidade e dignidade. Mas, os horizontes ampliam-se e reconhece-se a necessidade de se tutelar o 'meio ambiente' e a sua completude para garantir 
ao homem uma sadia qualidade de vida atual e para as gerações vindouras (art. 225, caput da CR).

A rinha de galo causa espanto pela forma com que os animais, em geral, da raça gallus-gallus são tratados antes da luta e, também, quando lançados à arena. A indignação aumenta no momento em que se percebe a prática como puro entretenimento ou jogo de apostas.

\subsection{Breve histórico normativo sobre a Rinha de Galos}

A briga das aves é prática milenar. Aparece em documentos e pesquisas históricas, primeiramente, no ano 5.000 a.C, no Código de Manu, antiga legislação da Índia, no qual existia as regras para as competições. Na Grécia antiga a atividade intensificou-se com o objetivo de se incentivar o espírito guerreiro, espalhando-se por toda a Europa. Com o advento das Grandes Navegações e a consequente colonização, a prática difundiu-se pelo mundo. No Brasil, foram os espanhóis, por volta do ano 1530, os responsáveis pela implantação do evento que se espalhou e encontrou adeptos por todo o território de influência europeia, popularizando-se (ESCOBAR; AGUIAR, 2012).

Nos primórdios de sua chegada ao Brasil, a rinha não teve proibições legais e não sofreu movimentações contrárias a sua realização. Apenas em 10 de julho de 1934, com o Decreto Federal n ${ }^{\circ} 24.645$, promulgado pelo presidente Getúlio Vargas, estabeleceu-se medidas protetivas aos animais, fixando punições. As rinhas, entretanto, não foram mencionadas, as touradas, sim, sendo exemplo de lutas entre animais.

Em 03 de outubro de 1941, na Lei de Contravenções Penais, no art. 64, proibiu-se a crueldade contra os animais. Polêmicas sobre a referida lei e a própria legalidade das rinhas e jogos de azar geraram a liberdade para a sua prática por 20 anos (ESCOBAR; AGUIAR; ZAGUI, 2014).

Em 18 de maio de 1961, o presidente Jânio Quadros, editando o Decreto $\mathrm{n}^{\mathrm{o}} 50.620$, obstou expressamente a briga de galos, vedando, igualmente, qualquer espetáculo cuja atração envolva luta de animais de qualquer espécie. $\mathrm{O}$ ato do presidente de proteção aos animais aconteceu em uma época em que foi reputado bizarrice, sendo atacado e contestado pela imprensa (ESCOBAR; AGUIAR; ZAGUI, 2014).

Na verdade, essa insatisfação com a proibição aconteceu em razão de a prática envolver apostas e gerar circulação de dinheiro nos eventos. Logo após, em 1962, o então primeiro-ministro Tancredo Neves revogou a norma proibitiva com a edição do decreto $n^{\circ} 1233$, possibilitando, novamente, as rinhas. A conduta permaneceu lícita até a promulgação da Lei n ${ }^{\circ} 9.605 / 1998$, quando se criminalizou 
A rinha de galos, o direito dos animais e o meio ambiente na ótica do STF - uma anÁlise da ADI 1856/RJ

as práticas de maus-tratos a animais, coibindo as brigas de galos (ESCOBAR; AGUIAR; ZAGUI, 2014). Desde este marco, pós-constituição de 1988, a crueldade contra os animais é criminalizada no ordenamento jurídico brasileiro. ${ }^{1}$

\subsection{Maus-tratos cometidos contra as aves e a ocorrência de crime ambiental}

Não há dúvidas de que o exercício, de expor as aves a ambientes de competição e treiná-las para o combate seja cruel. Inclusive, verificam-se várias partes do corpo com graves mutilações, alcançando-se, muitas vezes ou na maioria delas, o óbito. No voto do Ministro relator há uma extensa descrição das condições cruéis às quais são submetidos os animais, advinda de fragmento contido na Apelação Cível $n^{\circ}$ 479.743/PE, da qual ele se socorreu como elemento ilustrativo e motivador da decisão. Utilizaremos, entretanto, uma descrição mais resumida e não menos esclarecedora de Giselle Hirata:

Matar ou morrer. Desde pequenos, os galos são treinados para enfrentar, sem medo, o seu adversário.

Tipos de galo. São da espécie gallus-gallus, que são mais selvagens e ariscos. (...)

Tosa. Não é uma regra, mas muitos criadores costumam aparar as penas dos galos, principalmente quando as brigas são realizadas em locais quentes. (...) Segundo os criadores, a tosa facilita massagens e o controle de parasitas. (...)

Acessórios. Os galos também têm apetrechos: a biqueira, um bico postiço de metal que é colocado sobre o natural como proteção, e as esporas, que têm $2,5 \mathrm{~cm}$ de comprimento e servem como armas. Feitas de plástico, elas são

\footnotetext{
Oportuno apontar a existência de projeto de lei (PL no 2.833-D/2011) apresentado pelo Deputado Federal Ricardo Tripoli (PSDB-SP) que "criminaliza condutas praticadas contra cães e gatos, e dá outras providências". O projeto de lei foi analisado e aprovado pelo Plenário da Câmara dos Deputados em Sessão Deliberativa Extraordinária, na data de 29.04.2015. A matéria foi remetida ao Senado Federal para continuidade do processo legislativo. Eis a justificativa para a norma em trâmite - "Os princípios de não violência e a busca pelo embasamento ético na condução de ações individuais e coletivas norteiam o clamor social pela mudança de paradigmas, de preceitos culturais e impõe o respeito à vida de todos os seres vivos como condição de civilidade e sobrevivência dos ecossistemas e, por conseguinte, da própria espécie humana. É cediço que crimes cometidos contra os animais afetam a sensibilidade comum. Há pouco, notícias de barbáries eram desqualificadas e nem sempre provocavam clamor público. Hoje, em função da amplificação dos meios de comunicação e do advento das redes sociais, se tem acesso a cada vez mais casos de agressões contra seres vivos. $\mathrm{E}$ os atos de crueldade contra cães e gatos, cujo convívio com o homem se estreitou ao longo dos tempos, também se noticiam mais frequentes" (BRASIL, Projeto de Lei $\mathrm{n}^{\circ}$ 2.833-D/2011. Disponível em <http://www.camara.gov.br/proposicoesWeb/prop_mostrarintegra;jsessionid=885D5 B0749AB6097E BE68F85AD093335.proposicoesWeb1? codteor $=946117 \&$ filename $=$ TramitacaoPL+2833/2011> acesso em 12.05.15).
}

Revista do Direito Público, Londrina, v.10, n.3, p.91-118, set./dez.2015 | DOI: 10.5433/1980-511X.2015v10n3p91 
fixadas sobre as esporas naturais do galo, geralmente, com esparadrapos. (...)

Inscrição. É feita por ordem de chegada. Os galos são medidos e pesados pela comissão da rinha, que coloca uma anilha (uma pulseira para identificação) no tornozelo da ave. (...) Com os combates definidos, os donos dos galos combinam o preço da luta.

Resultado. No nocaute, o juiz abre uma contagem de tempo. Se a ave não se levantar durante os 10 segundos, perde a luta. O combate pode ser interrompido, caso o juiz perceba que um dos galos está sem condições de continuar - é o nocaute técnico. Se um galo parar de lutar, ele perde por desistência. $\mathrm{O}$ empate ocorre quando não houver decisão no tempo regular da briga. (...)

Treinamento. A preparação do galo pode durar de 30 a 90 dias, depende do rendimento. $\mathrm{O}$ treino inclui, basicamente, três exercícios:

Bater asa: com as batidas de asa, o galo trabalha os músculos peitorais e aumenta a capacidade respiratória.

Correr. A mesa giratória trabalha os músculos das (sic) coxas. A rotação aumenta gradualmente.

Pular. Impulsionar o galo para cima exercita asas e coxas. A altura do salto aumenta de acordo com a evolução (HIRATA, 2008).

É nítida a ausência de proteção e cuidado com o galo. Eles são usados como objetos para satisfazer o sadismo do homem de os ver guerreando até a morte. Em razão do sofrimento, o crime ambiental inicia-se, como se vê da descrição alhures, muito antes da entrada na arena.

A própria preparação dos animais para a luta incide nas elementares do tipo legal, pois a amputação das esporas para fixação das artificiais e a retirada das penas do ventre e das asas para a melhor refrigeração durante a luta, configuram-se nas ações de 'ferir' e 'mutilar' (MILARÉ, COSTA JR; COSTA, 2012). Vejamos o art. 32, caput da Lei n ${ }^{\circ}$ 9.605/1998: "Praticar ato de abuso, maus-tratos, ferir ou mutilar animais silvestres, domésticos ou domesticados, ativos ou exóticos - pena: detenção, de três meses a um ano, e multa" (BRASIL, 1998).

\section{A PROTEÇÃO DOS ANIMAIS (FAUNA) CONTRA A CRUELDADE NA CONSTITUIÇÃO DE 1988}

A Constituição protegeu a fauna de maneira ampla, indicou como foco de preocupação e tutela a totalidade do meio ambiente. Verificamos, aí, que se 
A rinha de galos, o direito dos animais e o meio ambiente na ótica do STF - uma anÁlise da ADI 1856/RJ

protege os animais e a coletividade, presente e futura, para que se tenha um ambiente ecologicamente equilibrado. Incumbe, ao Poder Público e a cada indivíduo, o dever de promover a manutenção da estabilidade ecológica. Tratase de uma norma-instrumento que possibilita uma consciência social, mesmo que tardia, sobre os direitos da fauna e do ser humano em relação a ela.

As Constituições brasileiras anteriores à atual não contemplavam a proteção ao meio ambiente de maneira específica. Hoje temos uma tutela ampla e moderna sobre a questão ambiental, possuindo capítulo próprio, dentro do título da 'Ordem Social', entretanto, o amparo não se resume a este capítulo VI 'do meio ambiente', e, sim, permeia diversos dispositivos ao longo do Texto.

A fauna é particularizada e tem 03 (três) vertentes de proteção, descritas no art. $225, \S 1^{\circ}$, inciso VII da CR, a saber: i) vedadas as práticas que coloquem em risco sua função ecológica; ii) provoquem a extinção de espécies ou iii) submetam os animais a crueldade. A fração que nos interessa primordialmente, no momento atual, é aquela afeta à submissão dos animais à crueldade.

Aqui, vislumbramos a norma-instrumento que dá garantia e efetividade à norma contida no enunciado principal (art. 225, caput da CR). O caput é a norma-princípio ou norma-matriz, reveladora do direito geral ao meio ambiente ecologicamente equilibrado e o $\S 1^{\circ}$ contém as normas que possibilitarão a eficácia do princípio geral. São as normas-instrumento, "que outorgam direitos e impõem deveres" (SILVA, 2008, p. 85) ao Poder Público e a coletividade para garantir ao setor ambiental, que figura como objeto, uma existência adequada nos padrões dispostos no Texto Maior.

O constituinte não nos concedeu a exata definição ou o conceito preciso do termo fauna. A lacuna poderia ser suprida pela Lei 5.197/67 em seu art. $1^{\circ}$, caput:

Os animais de quaisquer espécies, em qualquer fase do seu desenvolvimento e que vivem naturalmente fora do cativeiro, constituindo a fauna silvestre, bem como seus ninhos, abrigos e criadouros naturais são propriedades do Estado, sendo proibida a sua utilização, perseguição, destruição, caça ou apanha (BRASIL, 1967).

A referida legislação infraconstitucional, entretanto, restringiu o termo fauna, à fauna silvestre. Tanto que um dos argumentos dos interessados pela improcedência da ação direta de inconstitucionalidade girou em torno da definição de fauna para a Constituição. Sustentou que se limitava a sua fração silvestre, não abrangendo os animais domesticados como as aves combatentes, que, desta 
forma, passariam longe da proteção contra crueldade descrita no at. $225, \S 1^{\circ}$, inciso VII da CR. Tal entendimento, entretanto, encontra-se em total desalinho com o comando constitucional.

Entende-se por fauna, "o conjunto dos animais que vivem, ou viveram, numa determinada região, ambiente ou período geológico” (MILARÉ, 2013, p. 552), não há, portanto, motivo para se excluir qualquer ser vivo irracional da abrangência do conceito de fauna. As características que os particularizam são importantes em outras circunstâncias e não para diminuir a proteção. Cabenos, pelo menos apresentá-las a título de ilustração:

Constituem espécimes silvestres, (...) "todos aqueles pertencentes às espécies nativas, migratórias e quaisquer outras, aquáticas ou terrestres, que tenham todo ou parte de seu ciclo de vida ocorrendo dentro dos limites do território brasileiro, ou águas jurisdicionais brasileiras". Animais domésticos são aqueles que convivem harmoniosamente com o homem, do qual geralmente dependem; domesticados são espécies não-originariamente domésticas, mas que foram em tais convertidas, através do convívio com o homem. Nativos são os animais originários de um determinado lugar ou região, enquanto exóticos são os animais provenientes de outro local que não aquele em que se encontram (PRADO, 2001, p. 69/70).

Não há dúvidas de que a fauna, em toda a sua abrangência, é bem jurídico protegido. A fauna deve ser vista como bem jurídico ambiental constitucional de natureza difusa e elemento indissociável do 'macrobem', meio ambiente. A reunião de todos os fatores envolvidos e equilibrados é essencial à sadia qualidade de vida das gerações presente e futura (PADILHA, 2010).

O STF, na ADI em estudo, posiciona-se no sentido de que o termo fauna abraça todas as classificações expostas sobre os animais.

(...) os animais domésticos, como os galos, acham-se abrangidos pelo conceito genérico de fauna, o que permite estender, na linha da jurisprudência desta Corte, também às aves utilizadas em "brigas de galos", a proteção estabelecida no art. 225, § $1^{\circ}$, inciso VII, da Constituição da República (BRASIL, Supremo Tribunal Federal, ADI 1856, Relator Min. Celso de Mello, 2011,p. 310).

(...)

O art. 64 da Lei das Contravenções Penais foi revogado pela Lei 9.605, de 12/ 02/98, que dispõe sobre as sanções penais e administrativas motivadas por condutas e atividades lesivas ao meio ambiente, dentre as quais a prática de 
A rinha de galos, o direito dos animais e o meio ambiente na ótica do STF - uma análise da ADI 1856/RJ

crueldade contra animais silvestres, domésticos ou domesticados, sejam eles nativos ou exóticos, como resulta claro do art. 32 do referido diploma legislativo (BRASIL, Supremo Tribunal Federal, ADI 1856, Relator Min. Celso de Mello, 2011, p. 330).

Dessa forma, todos os animais estão protegidos de ações cruéis. A crueldade é definida como "qualidade de cruel; maldade; perversidade. Ato cruel". O termo cruel, por sua vez, é conceituado como aquilo "que maltrata, malvado; que causa sofrimento; pungente, doloroso; insensível, duro, intransigente; sangrento, sanguinolento; contrário ao que se desejava" (ACADEMIA BRASILEIRA DE LETRAS, 2009, p. 881).

A Constituição protege os animais, buscando salvaguardar o ser humano, pois a saúde psíquica do homem não lhe permite presenciar práticas cruéis, de sofrimento do animal (FIORILLO, 2012). A proteção aos animais funda-se no sentimento humano, portanto, é o homem o referencial que determina o que é cruel. "A crueldade só estará caracterizada se a prática contra o animal não tiver por finalidade proporcionar ao homem uma sadia qualidade de vida ou, na hipótese de estar presente o propósito, os meios empregados não forem os absolutamente necessários à atividade" (FIORILLO, 2012, p. 288). O fundamento da dignidade humana atrelado à vedação da crueldade contra os animais foi utilizado pelos Ministros na decisão da ADI n $1856 /$ RJ.

Ministro Gilmar Mendes, se Vossa Excelência me permite intervir - não, evidentemente, para servir de fundamento, porque não seria o caso, mas para pensar -, acho que a regulamentação não está apenas proibida pelo art. 225; acho que a lei ofende também a dignidade da pessoa humana, porque, na verdade, implica, de certo modo, um estímulo às pulsões mais primitivas $\mathrm{e}$ irracionais do ser humano.

(...) Noutras palavras, a proibição também deita raiz nas proibições de todas as práticas que promovem, estimulam e incentivam ações e reações que diminuem o ser humano como tal e ofendem, portanto, a proteção constitucional à dignidade da pessoa humana, que é fundamento da República.

(...) Porque está em jogo exatamente esse princípio básico da dignidade da pessoa humana. Quando se trata cruelmente ou de forma degradante um animal, na verdade está se ofendendo o próprio cerne da dignidade humana (BRASIL, Supremo Tribunal Federal, ADI 1856, Relator Min. Celso de Mello, 2011,p.336). 


\subsection{A Declaração Universal dos Direitos dos Animais}

A proteção aos animais encontra amparo não só nos ordenamentos jurídicos, ou seja, de maneira interna nos países, mas, também, na relação entre as Nações e seu compromisso com a humanidade e com o meio ambiente. A UNESCO proclamou, em 27 de janeiro de 1978, em Bruxelas, a Declaração Universal de Direitos dos Animais, documento de relação internacional do qual o Brasil é signatário. Por ele, os animais possuem a sua própria dignidade que deve ser respeitada, não podendo nenhum animal ser explorado para divertimento do homem.

A concepção de globalização no trato ambiental aconteceu na Conferência das Nações Unidas sobre o meio ambiente ocorrida em 1972, em Estocolmo na Suécia. O resultado deste entendimento universal gerou resoluções e recomendações que materializaram as 'convicções comuns' dos Estados participantes. Os princípios de Estocolmo indicam a conjugação harmônica do desenvolvimento com a preservação ambiental (REZEK, 2002).

Nessa vertente, despontam, posteriormente, outras convenções e declarações que reúnem os países em propósitos convergentes de proteção e respeito ao meio ambiente em sua completude. A Declaração dos Direitos dos Animais é corolário lógico da evolução histórica alcançada pela tutela ambiental.

A regra não permissiva relativa à questão do divertimento do homem com os animais descrita na Declaração Internacional em menção, não foi abordada na decisão do STF. Os Ministros consideraram a prática como repugnante e atentatória desde o início, não se debruçando a este argumento. Não houve a ponderação de valores em rota de colisão em relação ao direito ao lazer ou a atividades culturais e folclóricas e a proteção dos direitos da fauna e o meio ambiente.

Nem se diga que a briga de galos qualificar-se-ia como atividade desportiva ou prática cultural ou ainda, como expressão folclórica, numa tentativa de fraudar a aplicação da regra constitucional de proteção da fauna, vocacionada, dentre outros nobres objetivos, a impedir a prática criminosa de atos de crueldade contra os animais (BRASIL, Supremo Tribunal Federal, ADI 1856, Relator Min. Celso de Mello, 2011, p. 313/314).

Não poderíamos, entretanto, deixar de mencionar a Declaração Universal, uma vez que a Assembleia Legislativa do Estado do Rio de Janeiro em suas informações sustenta e propõe que a rinha de galos seja entendida como prática 
esportiva e como fator de integração social entre as comunidades do interior do Estado. Assim, claro está, também, o impedimento de atividades exploratórias de animais para deleite humano.

O homem moderno que, na prática 'lúdica', utiliza-se de animais e de seu sofrimento para se entreter, aproxima-se das grandes matanças do homem pré-histórico e de uma identidade perversa que demonstra a total insensibilidade face a outro ser vivo. Já passou da hora de despertarmos socialmente e através do Poder Judiciário para coibir tais irracionalidades (PINHEIRO; BEDRAN, 2014). Trata-se de prática reconhecida como especismo e que encontra paralelo em outras conformações sociais segregantes e discriminatórias.

No especismo, o animal humano, ignorando que os animais não humanos sencientes são capazes de experimentar o prazer e a dor, deles se utiliza para uma enorme gama de fins, sem preocupar-se com a efetiva necessidade de tal uso e tampouco com os sofrimentos que lhes são impostos (PINHEIRO; BEDRAN, 2014,p. 234).

Vemos, então, que a proteção e o impedimento a práticas cruéis com os animais é fato inconteste. O que fica para ser debatido e verificado é a posição ocupada pelos animais e pelo próprio meio ambiente nesta tutela.

\section{A PROTEÇÃO DO MEIO AMBIENTE E A CONSTITUIÇÃO DA REPÚBLICA NA CONCEPÇÃO DO STF NO JULGA- MENTO DA ADI 1856/RJ}

A Constituição da República promulgada em 05 de outubro de 1988 é a primeira Carta Política brasileira a tratar a questão ambientalista de forma deliberada. Ela é uma Constituição eminentemente ambientalista, abordando o tema como direito fundamental dos indivíduos. Trabalha-o em capítulo específico e não no art. $5^{\circ}$ da $\mathrm{CR}$, local onde os direitos básicos, essenciais, das pessoas são protegidos e elencados. Mas, esse distanciamento não o inferioriza ou desprestigia, apenas o especializa, tornando, ainda mais clara a sua importância. É, nitidamente, um direito fundamental porque necessário à sobrevivência sadia e digna do homem, constituindo parte do mínimo existencial, sem o qual é impossível a manutenção do ser humano na Terra. Não estão descritos no art. $5^{\circ}$ da CR, mas são decorrentes de outro regime e princípios adotados pela Norma Maior e provenientes de tratados internacionais 
em que a República Federativa do Brasil faz parte, conforme preceitua o $§ 2^{\circ}$ do art. $5^{\circ}$ da CR.

A tônica da decisão do STF é a verificação da validade jurídica da lei contestada perante a Constituição. Para tanto, é necessário observar a existência do valor debatido perante a Lei Maior de um Estado. Tal análise atinge a ideia de justiça e, por conseguinte, a ideia de ética e de dignidade. "O mecanismo mais eficaz para corrigir injustiças e garantir eticidade para as ações humanas é o direito. O direito pode ser examinado sob o ponto de vista legal ou sob o ponto de vista ético" (NOGUEIRA, 2012, p. 299). Verifica-se, na decisão em estudo, que ambos os vetores de análise (direito e ética) foram trabalhados pelos Ministros que descortinaram a prática da rinha de galos nos valores basilares envolvidos nesta celeuma e na sua correspondência com a norma posta.

Resulta, pois, da norma constitucional invocada como parâmetro de confronto (CF, art. $\left.225, \S 1^{\circ}, \mathrm{VII}\right)$, o sentido revelador do vínculo que o constituinte quis estabelecer ao dispor que o respeito pela fauna em geral atua como condição inafastável de subsistência e preservação do meio ambiente em que vivem os próprios seres humanos.

Evidente, desse modo, a íntima conexão que há entre o dever ético-jurídico de preservar a fauna (e de não incidir em práticas de crueldade contra animais), de um lado, e a própria subsistência do gênero humano em um meio ambiente ecologicamente equilibrado, de outro (BRASIL, Supremo Tribunal Federal, ADI 1856, Relator Min. Celso de Mello, 2011, p. 295).

O escopo máximo que se pretende atingir com o reconhecimento da inconstitucionalidade da lei que regula a prática da briga de galos é o restabelecimento da dignidade do homem, comprometida com o comportamento violento gerado pela prática descrita e retomar a construção e a convivência em uma sociedade democrática. A democracia não existe sem a proteção de direitos e respeito aos direitos fundamentais. A interação entre democracia e direitos fundamentais, nos quais estão descritos os direitos ao meio ambiente, encontram anteparo nos direitos humanos, precisamente, naqueles surgidos em sua terceira dimensão.

Antes, entretanto, adentrar aos direitos humanos e à dignidade humana, temos que voltar o olhar sobre a posição do STF acerca da tutela do meio ambiente. É ela fundada no homem (antropocêntrica) ou de raízes na própria natureza (biocêntrica)? Qual a matriz teórica da Corte Suprema para conceber a proteção ao meio ambiente? 


\subsection{Antropocentrismo e biocentrismo}

O antropocentrismo é o entendimento teórico de que o ambiente existe para a subsistência e existência humana, apenas. Todos os fatores protetivos ambientais estarão voltados a uma melhor qualidade de vida para o homem. Já a corrente biocentrista analisa o meio ambiente sob ótica própria, a partir da compreensão de que os seus elementos integrantes são o foco primevo dos direitos ambientais.

A posição antropocêntrica origina-se do modelo tradicional, no qual o meio ambiente e, por consequência, os seus elementos constitutivos devem existir para o bem-estar do homem e para a sua felicidade exclusiva. A proteção dos animais e do ambiente apenas se daria em razão do homem. Todos os aspectos protetivos originar-se-iam da sua utilidade para o bem do ser humano. Os demais seres possuem uma função subalterna e sujeitam-se ao homem (PADILHA, 2010).

O antropocentrismo, hoje, possui uma visão mais abrandada, mas teve momentos em que alcançou posições e entendimentos extremos.

A teoria antropocêntrica surgiu com os filósofos gregos que colocavam o homem como medida de todas as coisas. A teoria foi ampliando e encontrou seu ápice e sua vertente mais radical no século XVII, na Teoria do Método de René Descartes que trouxe a ideia do animal-machine (animal-máquina), negando a racionalidade dos bichos, assim como suas emoções e sensações. Trata-se da visão cartesiana sobre os animais e o homem.

Nesse paradigma, os corpos animais e humanos não possuíam sentimentos como dor, prazer, sofrimentos, pois estes sentimentos habitavam a alma e apenas o segundo - o animal humano - os possuía. Desta forma, não se deveria preocupar com o sofrimento animal, já que não existiam. Seus uivos e contorções deveriam ser interpretados como meros reflexos externos (VELOSO, 2013).

O antropocentrismo, atualmente, é concebido dentro da concepção de que o meio ambiente deve ser protegido para propiciar uma vida digna e sadia ao homem. O parâmetro principal permanece sendo o homem, mas não com a agressividade e o desequilíbrio visto nas concepções de outrora.

O biocentrismo ou ecocentrismo, por sua vez, entende que os animais não humanos possuem dignidade e que devem ser reconhecidos como um fim em si mesmos e não através do homem. Os animais são dotados de valores e têm os mesmos valores intrínsecos aos conferidos ao homem. "Tais considerações implicam o reconhecimento de deveres jurídicos a cargo dos seres humanos, tendo como beneficiários os animais não humanos e a vida em geral" (SARLET, 
2014, p. 55). "O homem não é superior aos outros seres vivos, mas parte integrante da natureza: mantém com eles uma relação de interdependência, de simbiose. O centro das relações não é, como no antropocentrismo, a humanidade, mas os seres vivos" (OLIVEIRA, 2010, p. 21). Os homens, portanto, podem ter limitações de direitos fundamentais em razão do reconhecimento de interesses (jurídico-constitucionais) aos não humanos ou quem sabe até a possibilidade de entendimento dos animais como sujeitos de direitos (SARLET, 2014).

Qual, então, é a teoria adotada pelo Supremo Tribunal Federal na decisão da ADI 1856/RJ? Muitos acreditam que a proteção específica conferida à fauna, por si só, já demonstra uma vertente ecocentrista pelo constituinte e que é acompanha pelo STF em suas decisões quando entende que o animal não pode sofrer práticas caracterizadas como tortura e não podem ser subjugados por atos de crueldade para satisfazer o homem. Nossa ótica, entretanto, é de que permanece a visão antropocentrista, mas, com uma postura mais aberta e proporcional à amplitude dos conhecimentos científicos em relação ao animal, bem como diante das conquistas filosóficas envolvendo a essência da vida.

A fauna não aparece como um sujeito pleno de direitos na decisão e nos debates da Corte Suprema. Ela é protegida por ato reflexo ao homem. Protegese e veda-se a prática de atividades repugnantes por parte do homem, pela qual ele mostra a sua maldade e violência em potencial. Observemos uma das manifestações dos Ministros durante os debates: "A ausência de lei não pode significar nesse contexto autorização para torturar um ser vivo, até porque da tortura de um galo para a tortura de um ser humano é um passo. Então, não podemos deixar de coibir, com toda a energia, esse tipo de prática" (BRASIL, Supremo Tribunal Federal, ADI 1856, Relator Min. Celso de Mello, 2011, p. 326).

Assim, vislumbramos inequivocamente que a posição é sempre de proteger o meio ambiente, mais diretamente, neste caso, a fauna, mas sempre, sob o olhar e a tutela do homem em sua humanidade.

Saliente-se que os animais não são sujeitos de direito. Protege-se a fauna para dar vazão a mandamento constitucional consistente em garantir à presente e futura geração um meio ambiente equilibrado. O sujeito de direito é o homem, sendo que os animais tem sua integridade tutelada por via reflexa (MILARÉ; COSTAJR. COSTA, 2012, p. 81).

Percebemos, portanto, um antropocentrismo alargado, mitigado ou um antropocentrismo de inspiração biocêntrica. $\mathrm{O}$ homem não é mais o interesse 
único na proteção do meio ambiente. Reconhecem-se os valores inerentes ao meio ambiente, aos seus elementos constitutivos, mas, não deixa, o homem, de ser o fim último da análise e percepção da natureza e de seu fundamental equilíbrio.

Estamos em momento 'animal welfare', faltando-nos, se um dia chegarmos, uma longa caminhada para o reconhecimento e/ou adoção do 'animal right'.

A posição que defende o "bem-estar" assume como legítimo o tratamento instrumental dos animais (como meios para fins humanos), desde que certas "salvaguardas" sejam utilizadas. Sinteticamente, no que diz com a exploração animal, seria como se os "welfaristas" defendessem sua regulamentação, enquanto os que postulam pelos "direitos dos animais" buscassem sua abolição. A posição de "bem-estar" trabalha com dois conceitos básicos, quais sejam, $o$ tratamento "humanitário" e a eliminação do "sofrimento desnecessário", no sentido de que é aceitável ultrapassar quaisquer interesses animais - inclusive a dor e a morte -, desde que o interesse humano envolvido seja reputado "significativo" e o sofrimento animal não seja "desnecessário". Em geral, a "necessidade" do padecimento é analisada sob o prisma das práticas socialmente aceitas. As reputadas "cruéis" são, na maior parte das vezes, somente aquelas que "desperdiçam" os "recursos animais" por meio da imposição de "sofrimento gratuito" (LOURENÇO, 2008, p. 388).

Trata-se um antropocentrismo alargado, pois há uma interação entre a proteção do homem e a proteção dos demais seres vivos, entretanto, não prevalece uma relação de superioridade do homem como ocorre nos parâmetros clássicos do antropocentrismo (OLIVEIRA, 2010). Estabelece-se uma postura ética no trato com os demais seres que habitam o planeta, na busca constante de um ambiente equilibrado e na luta em deixar esta herança para as próximas gerações.

O antropocentrismo é, portanto, a tônica analítica da decisão em questão. O homem é um ser social e diante de suas necessidades é que se desenvolveu a ciência do Direito. Não existiriam controvérsias passíveis de solução se não houvesse homens racionais convivendo, discutindo e questionando os demais componentes da sociedade e suas ações no seio da comunidade As condutas, ético-jurídico-morais, devem ser tuteladas e resguardadas para se garantir a dignidade humana, as relações interpessoais e a proteção do meio de convivência (entendido como ambiência) para as gerações do porvir. 


\subsection{Uma reunião dos conceitos de dignidade humana, meio ambiente e direitos humanos}

A dignidade humana é fundamento da República Federativa do Brasil, exposto em seu no art. $1^{\circ}$, inciso III. Ela reúne em si todos os direitos e garantias fundamentais relativos ao exercício da humanidade conferidos ao homem. Tratase de um valor inerente a todos os indivíduos e que se manifesta em sua autodeterminação consciente e responsável. Podemos observar que a única atuação compatível com o ser humano e sua dignidade são aquelas de respeito ao meio ambiente e distante de atitudes cruéis direcionadas a qualquer ser vivo dotado de sensibilidade.

Por essa razão o STF sustentou toda a decisão da ADI 1856/RJ na dignidade da pessoa humana que de fato fica comprometida com atitudes de tortura que não podem jamais ser identificadas como práticas culturais, porque o homem evoluiu em sua humanidade, não sendo possível aceitar e compreendêlo hoje como alguém que se representa culturalmente e ideologicamente através de crueldade aos animais. Observemos a análise acerca da norma preceituada no art. $225, \S 1^{\circ}$, inciso VII da $\mathrm{CR} / 88$ :

Se prestarmos atenção ao texto, data vênia, vamos perceber que esse dispositivo não vem isolado; ele não veio num piscar de olhos do constituinte, digamos assim, de rompante; ele faz parte de todo um contexto constitucional, que principia com o próprio preâmbulo da nossa magna Carta, que fala de uma sociedade fraterna, pluralista e sem preconceitos. (...)

Aliás, eu até diria que uma Constituição promulgada explicitamente sob a proteção de Deus é absolutamente repelente desse tipo de autoexecução de animais entre si. (...)

Agora, eu só quero terminar dizendo o seguinte: essa crueldade, caracterizadora de tortura, manifesta-se no uso do derramamento de sangue e da mutilação física como um meio, porque o fim é a morte. O jogo só vale se for praticado até a morte de um dos contendores, de um dos galos, que são seres vivos. Quer dizer, é um meio. Derramar sangue e mutilar físicamente o animal não é sequer o fim. O fim é, verdadeiramente, a morte de cada um deles; a briga até a exaustão e a morte. E não se pode perder a oportunidade para que a Suprema Corte manifeste o seu repúdio, com base na Constituição, a esse tipo de prática, que não é esporte nem manifestação de cultura (BRASIL, Supremo Tribunal Federal, ADI 1856, Relator Min. Celso de Mello, 2011, p. 323/325).

O termo dignidade humana e a carga principiológica por ele trazida é que permite a proteção do meio ambiente na concepção mais adequada a uma 
A rinha de galos, o direito dos animais e o meio ambiente na ótica do STF - uma anÁlise da ADI 1856/RJ

existência responsável coletivamente. Refere-se à dignidade humana e não se limita apenas à vida humana (expressão menos flexível), garantindo consequentemente proteção às gerações futuras que ainda não possuem a vida material (HABERMAS, 2004). Surgindo, consequentemente, a ligação entre a dignidade humana e o compromisso intergeracional - deixar um ambiente sadio e equilibrado para as gerações vindouras.

A dignidade humana é realmente o fio condutor da interpretação e da decisão proferida pelo Supremo Tribunal Federal e tem que ser mesmo, pois fundamento da República brasileira e norte estabelecido para compreensão da existência humana nos parâmetros historicamente construídos e nas fases em que se estabeleceram os direitos humanos ou os direitos fundamentais. Toda a evolução dos direitos do homem, seu dinamismo e processo histórico estiveram atrelados à característica imutável do homem de ser digno.

A dignidade humana, embora seja formada de um núcleo jurídico mínimo que tutela a existência humana, não é um conceito jurídico puro, é filosófico, histórico e, com problematização trazida pela contemporaneidade da bioética, é também biológico e ecológico. (...) Formaram-se os direitos liberais (liberdade e igualdade), posteriormente os direitos sociais (integridade física e moral) e agora a dignidade ganhou uma dimensão comunitária (solidariedade). "A dignidade do indivíduo nunca é a do indivíduo isolado ou socialmente irresponsável. Projeta-se na dignidade de todos os integrantes do grupo social”. Tal pensamento coaduna perfeitamente com a nova função social e moralizadora do neoconstitucionalismo e da Teoria Crítica do Direito. A dogmática jurídica contemporânea, através da dimensão solidariedade, dá ao valor dignidade um conceito elástico para além da humanidade. Inclui uma dimensão ecológica para incluir a vida como um todo, um reclame do Estado socioambiental (NOGUEIRA, 2012, p. 294).

Assim, a dignidade humana vincula-se intimamente a todas as ações e tutelas destinadas ao homem, principalmente naquelas em que seus direitos mais importantes (direitos fundamentais) estão expostos. Os direitos do homem foram elaborados e reconhecidos em um processo histórico, cuja característica central é a complementaridade solidária. Cada um dos grupos de direitos reconhecidos ao longo dos tempos são agregados, sem eliminar ou excluir os já reconhecidos. $\mathrm{O}$ meio ambiente foi abraçado em sua terceira dimensão, aquela que destaca os direitos de fraternidade. 
Com relação ao primeiro processo, ocorreu a passagem dos direitos de liberdade - das chamadas liberdades negativas, de religião, de opinião, de imprensa, etc. - para os direitos políticos e sociais, que requerem uma intervenção direta do Estado. Com relação ao segundo, ocorreu a passagem da consideração do indivíduo humano uti singulus, que foi o primeiro sujeito ao qual se atribuíram direitos naturais (ou morais) - em outras palavras, da "pessoa"-, para sujeitos diferentes do indivíduo, com a família, as minorias étnicas e religiosas, toda a humanidade em seu conjunto (como no atual debate, entre filósofos da moral, sobre o direito dos pósteros à sobrevivência); e, além dos indivíduos humanos considerados singularmente ou nas diversas comunidades reais ou ideais que os representam, até mesmo para sujeitos diferentes dos homens, como animais. Nos movimentos ecológicos, está emergindo quase que um direito da natureza a ser respeitada ou não explorada, onde as palavras "respeito" e "exploração" são exatamente as mesmas usadas tradicionalmente na definição e justificação dos direitos do homem(BOBBIO, 1992, p.69).

A convergência entre a dignidade humana, os direitos humanos e a proteção do meio ambiente é o referencial lógico do qual partiram os julgadores, sendo o paradigma de toda compreensão ambiental atual.

Importante observar que o meio ambiente foi inserido nos direitos humanos em sua dimensão de fraternidade, pela qual se observa a percepção de irmandade, de caminhar juntos e unir esforços para um bem comum. Os direitos humanos de terceira geração "têm primeiro por destinatário o gênero humano mesmo, num momento expressivo de sua afirmação como valor supremo em termos de existencialidade concreta" (BONAVIDES, 2005, p. 569). Tal visão é de suma importância para se inteligir o art. 225, caput da CR, quando se verifica que o dever de proteção do meio ambiente é comum ao Poder Público e a coletividade.

"Progresso imensamente maior foi a coletividade conquistar a posição de poder dividir com o Estado as responsabilidades ambientais. O triunfo do particular foi trazer a si parcela do exercício da função ambiental" - no entender de Antônio Herman V. Benjamin. A presença e a atuação da sociedade civil na defesa do meio ambiente revela-se como uma das marcas inconfundíveis do novo Direito Ambiental. (...)

A Constituição foi bem-formulada ao terem sido colocados conjuntamente o Poder Público e a coletividade como agentes fundamentais na ação defensora e preservadora do meio ambiente. Não é papel isolado do Estado cuidar sozinho do meio ambiente, pois essa tarefa não pode ser eficientemente executada sem a cooperação do corpo social (MACHADO, 2008, p. 129/130). 
Não há, portanto, diferenças na proteção, seja em relação ao objeto da proteção, seja em relação ao agente protetor, ambos possuem e agem voltados para o mesmo foco. Sua incidência é ampla e geral atingindo todo o ambiente. No nosso caso problema a tutela é conferida aos animais irrestritamente, sejam eles silvestres, domésticos, domesticados, nativos ou exóticos, todos devem ser resguardados de práticas que possam colocar em risco sua função ecológica e que provoquem maus-tratos ou os submetam a crueldade (ESCOBAR; AGUIAR, 2012).

Não há meio ambiente que segregue o homem. O ser humano é o agente propulsor das mudanças e evoluções do mundo. Cada indivíduo, em suas ações particulares, compõe a coletividade que tem o compromisso de proteger e sustentar o meio ambiente para a geração atual e para a futura. Aspecto que, em relação à fauna, abarca a não destruição (extinção) das espécies, a inexistência de risco ecológico e a proteção contra práticas cruéis que têm em si duplo efeito, atinge o meio ambiente diretamente e atinge o homem como componente do meio e como ser em particular-alertando-o sobre sua agressividade potencial (atingindo a ética e a alteridade) e sobre seu compromisso com o equilíbrio ecológico.

O meio ambiente é fundamental para a existência sadia do homem e ensina-o, também, a viver dignamente, em equilíbrio e em fraternidade.

\section{CONSIDERAÇÕES FINAIS}

A decisão do Supremo Tribunal Federal na Ação Direita de Inconstitucionalidade $n^{\circ} 1856$ que questiona a validade jurídica da Lei $n^{\circ} 2.896 /$ 98 promulgada pelo Estado do Rio de Janeiro e a dialética estabelecida constituem importante referencial para se compreender a tutela do meio ambiente e da fauna, especificamente. É relevante para se verificar a relação existente e estabelecida pela Constituição brasileira entre o homem (indivíduo), o Estado (Poder Público/Administração) e a coletividade.

Trata-se de um novo paradigma em que a proteção e administração de bens difusos compete ao Estado, mas também, e, principalmente, a cada um de nós. É marco na construção de nova vertente do direito ambiental e de uma sociedade democrática, assim como apontado pela Ministra Cármen Lúcia em seu voto.

Fica claro pelo julgado que a Constituição pretende um ambiente preservado e equilibrado. O resguardo deste bem fundamental para vida do 
homem atual e a existência sadia das futuras gerações é de responsabilidade do Poder Público e da coletividade. A fauna como integrante do macrobem (meio ambiente) adentra a este parâmetro e deve ser protegida. Mais que isso, os animais devem permanecer à margem de ações cruéis que degradam o ser irracional (animal) e vilipendiam o homem em sua dignidade.

Os referenciais normativos estão disponíveis, falta-nos a educação (formal e informal) para nos conscientizar da necessária mudança de postura da sociedade brasileira em relação à fauna. Falta-nos a atuação como sociedade democrática.

Não alcançamos a vertente biocentrista como pretendem alguns, mas um importante caminho foi percorrido com a proteção contra a crueldade, garantindo o respeito, (talvez a tão sonhada dignidade animal), ou, ao menos, exigindo a dignidade humana no trato com os seres vivos e o ambiente que os cerca.

Começamos a reconhecer como possível a proteção autônoma do meio ambiente. Estamos trabalhando o antropocentrismo de maneira mitigada, no qual outros elementos encontram amparo por sua importância particular e não apenas pelo olhar do homem, mas, também em razão do homem.

Temos o direito e o dever de desenvolver e realizar todas as práticas humanas para nosso lazer, deleite e desenvolvimento, mas temos o compromisso intergeracional de empreender nossas atividades de maneira sustentável, sem agressões que retirem o bem-estar, a justiça e a qualidade do ambiente em sua completude. Por respeito às gerações futuras temos o entendimento de aproveitamento racional dos elementos componentes do meio ambiente e a prática da tortura com animais está distante de ser conduta desejável do ponto de vista do equilíbrio ecológico.

O compromisso intergeracional implica no respeito em relação aos interesses da geração vindoura que, não podendo no tempo presente exercer seus direitos de cidadão, devem ser compreendidos em sua importância e respeitados para que a balança do equilíbrio pretendido pelo meio ambiente penda para a proteção daquilo que necessitarão para viver e viver dignamente.

A decisão da Corte Suprema apresenta-nos informações sobre a Rinha de Galos, o entendimento sobre o meio ambiente e um arcabouço de ideias sobre a tutela dos animais contra a crueldade. Faz sua interpretação e profere uma decisão voltada ao exato e pertinente cumprimento das diretrizes normativas postas em um horizonte de dignidade humana e ecológica, desenhado por uma Constituição reverenciada como cidadã. 
Os animais não podem sofrer atos de crueldade. São ações incompatíveis com a dignidade do homem e destoam do cenário jurídico edificado pela ordem constitucional de 1988. O meio ambiente deve, imperativamente, ser protegido de qualquer agressão, de forma holística para o bem do ser humano, da fauna, da flora e de todo o contingente de elementos que o constitui.

\section{REFERÊNCIAS}

ACADEMIA BRASIELIRA DE LETRAS. Dicionário Escolar da Língua Portuguesa. 2. ed. São Paulo: Companhia Editora Nacional, 2008. 1312p.

BOBBIO, Norberto. A Era dos Direitos. 14. tiragem. Rio de Janeiro: Campus, 1992.217p.

BONAVIDES, Paulo. Curso de Direito Constitucional. 16. ed. São Paulo: Malheiros, 2005. 808p.

BRASIL. Constituição (1988). Constituição da República Federativa do Brasil. Disponível em:?http://www.planalto.gov.br/ccivil_03/Constituicao/ Constituicao.htm.? Acesso em 30 mar. 2015.

BRASIL. Lei n. 9605, de 12 de fevereiro de 1998. Dispõe sobre as sanções penais e administrativas derivadas de condutas e atividades lesivas ao meio ambiente, e dá outras providências. Diário Oficial da União, Brasília, 13 fev. 1998 e retificada, 17 fev. 1998. Disponível em ?http:// www.planalto.gov.br/ccivil_03/Leis/L9605.htm?. Acesso em: 30.mar.2015.

BRASIL. Lei n. 5197, de 03 de janeiro de 1967. Dispõe sobre a proteção à fauna e dá outras providências. Diário Oficial da União, Brasília, 05 jan. 1967. Disponível em<http://www.planalto.gov.br/ccivil_03/Leis/L5197.htm>. Acesso em 09.abr.2015.

BRASIL. Supremo Tribunal Federal. Ação Direta de Inconstitucionalidade Briga de Galos (Lei fluminense n 2.895/98) - Legislação estadual que, pertinente a exposições e a competições entre aves das raças combatentes, favorece essa prática criminosa - diploma legislativo que estimula o cometimento de atos de crueldade contra Galos de Briga - crime ambiental 
$\left(\right.$ Lei $n^{\circ}$ 9.605/98, art. 32) - meio ambiente - direito à preservação de sua integridade ( $\mathrm{CF}$, art. 225) - prerrogativa qualificada por seu caráter de metaindividualidade - direito de terceira geração (ou de novíssima dimensão) que consagra o postulado da solidariedade - proteção constitucional da fauna (CF, art. 225, § 1 ${ }^{\circ}$, VII) - descaracterização da Briga de Galo como manifestação cultural - reconhecimento da inconstitucionalidade da lei estadual impugnada - Ação Direta Procedente. ADI 1856/RJ. ProcuradorGeral da República, Governador do Estado do Rio de Janeiro e Assembleia Legislativa do Estado do Rio de Janeiro. Relator Ministro Celso de Mello, Tribunal Pleno, 26.05.11. Disponível em: $<$ http://redir.stf.jus.br/paginadorpub/ paginador.jsp?doc $\mathrm{TP}=\mathrm{AC} \& \mathrm{docID}=628634>$ acesso em: 12.05.2015.

ESCOBAR, Marco Lunardi; AGUIAR, José Otávio. O Direito Animal em face da Espetaculização. O caso das rinhas de galo no nordeste brasileiro: isso é manifestação cultural?. Revista UNIABEU Belford Roxo, v. 5, n. 10, p. 274-286, maio-agosto 2012.

ESCOBAR, Marco Lunardi; AGUIAR, José Otávio; ZAGUI, Paula Apolinário. Galos em Combate na Paraíba: o descumprimento da legislação ambiental. Revista de Direitos Humanos e Democracia. Unijiú, ano 2, n. 4, p. 143-165, julho-dezembro 2014.

FIORILlO, Celso Antonio Pacheco. Curso de Direito Ambiental Brasileiro. 13. ed. São Paulo: Saraiva, 2012. 902p.

HABERMAS, Jürgen. O Futuro da Natureza Humana. São Paulo: Martins Fontes, 2004. 159p.

HIRATA, Giselle. Como é realizada uma briga de galo? Mundo Estranho, São Paulo, edição 110. Disponível em: ?http://mundoestranho.abril.com.br/ materia/como-e-realizada-uma-briga-de-galo? com acesso em 03.abr.2015.

LEITE, Fábio Carvalho. A Liberdade de Crença e o Sacrifício de Animais em Cultos Religiosos. Veredas do Direito, Belo Horizonte, v.10, n. 20, p. 163-177, julho-dezembro 2013.

LOURENÇO, Daniel Braga. Direito dos Animais: fundamentação e novas perspectivas. Porto Alegre: Sérgio Antônio Fabris, 2008. 566p. 
MILARÉ, Édis; COSTA JR, Paulo José; COSTA, Fernando José da.

Direito Penal Ambiental. 2. ed. São Paulo: Revista dos Tribunal, 2013. 295 .

MILARÉ, Édis. Direito do Ambiente. 8. ed. São Paulo: Revista dos Tribunais, 2013. 1614p.

NOGUEIRA, Vânia Márcia Damasceno. Direitos Fundamentais dos Animais: a construção jurídica de uma titularidade para além dos seres humanos. Belo Horizonte: Arraes, 2012. 404p.

OLIVEIRA. Fabiano Mel Gonçalves. Direitos Difusos: direito ambiental. 2. ed. São Paulo: Revista dos Tribunais, 2010. 252p. (Coleção Elementos do Direito, v. 15).

ONU. Declaração Universal dos Direitos dos Animais. Proclamada em Assembleia da UNESCO em Bruxelas, Bélgica, em 27 de janeiro de 1978. Disponível em $<$ http://www.apasfa.org/leis/declaracao.shtml $>$. Acesso em 04.abr.2015.

PADILHA, Norma Sueli. Fundamentos Constitucionais do Direito Ambiental Brasileiro. Rio de Janeiro: Elsevier, 2010. 452p.

PINHEIRO, Cristiano Cota; BEDRAN, Karina Marcos. Direito dos Animais em foco - comentários ao acórdão extraído do Recurso Especial n. 1.115.916-MG. In.: REZENDE, Élcio Nacur; BIZAWU, Kiwonghi (Orgs.). Direito Ambiental e Desenvolvimento Sustentável: uma redefinição da consciência ambiental planetária. Belo Horizonte: Escola Superior Dom Helder Câmara ESDHC, 2014. p 215-242.

PRADO, Luiz Regis. Crimes Contra o Ambiente. 2. ed. São Paulo: Revista dos Tribunais, 2001.352p.

REZEK, José Francisco. Direito Internacional Público: curso elementar. 9. ed. São Paulo: Saraiva, 2002. 406p. 
SARLET, Ingo Wolfgang; FENSTERSEIFER, Tiago. Direito

Constitucional Ambiental: constituição, direitos fundamentais e proteção do ambiente. 4. ed. São Paulo:Revista dos Tribunais, 2014. 382p.

SILVA, José Afonso da. Fundamentos constitucionais da proteção ambiental. In.: DAIBERT, Arlindo (Org.). Direito Ambiental Comparado. Belo Horizonte: Fórum, 2008. 412p.

VELOSO, Maria Cristina Brugnara. A Condução Animal: uma aporia moderna. Belo Horizonte: Arraes, 2013. 189p.

Artigo recebido em: 17/06/2015 Aprovado para publicação em: 25/11/2015

Como citar: LIMA, Carolina Carneiro. COSTA, Beatriz Souza. A rinha de galos, o direito dos animais e o meio ambiente na ótica do STF - uma análise da ADI 1856/RJ. Revista do Direito Público. Londrina, v.10, n.3, p.91-118, set/dez.2015. DOI: 10.5433/1980-511X.2015v10n3p91. ISSN: 1980$511 X$. 